Tersedia online di: http://ejournal-balitbang.kkp.go.id/index.php/bawal
e-mail:bawal.puslitbangkan@ gmail.com
BAWAL wIDYA RISET PERIKANAN TANGKAP
Volume 9 Nomor 1 April 2017
p-ISSN: 1907-8226
e-ISSN: 2502-6410
BAWAL
Nomor Akreditasi: 620/AU2/P2MI-LIPI/03/2015

\title{
HUBUNGAN PANJANG-BERAT, KEBIASAAN MAKANAN, DAN REPRODUKSI IKAN KAKAP MERAH (Lutjanus gibbus: FAMILI LUTJANIDAE) DI PERAIRAN SELATAN BANTEN
}

\section{LENGTH-WEIGHT RELATIONSHIP, FOOD HABITS, AND REPRODUCTION OF HUMPBACK RED SNAPPER (Lutjanus gibbus; FAMILY LUTJANIDAE) IN THE SOUTHERN PART OF BANTEN WATERS}

Prihatiningsih*1, Mohammad Mukhlis Kamal' ${ }^{2}$ Rahmat Kurnia ${ }^{2}$ dan Ali Suman ${ }^{1}$

${ }^{1}$ Balai Penelitian Perikanan Laut, Komp. PPS Nizam Zachman, Jalan Muara Baru Ujung, Penjaringan, Jakarta Utara 14440, Indonesia

${ }^{2}$ Institut Pertanian Bogor, Kampus IPB Dramaga Bogor, Jalan Raya Dramaga, Babakan, Dramaga, Babakan, Dramaga, Bogor, Jawa Barat 16680, Indonesia

Teregistrasi I tanggal: 06 April 2017; Diterima setelah perbaikan tanggal: 07 Juni 2017; Disetujui terbit tanggal: 14 Juni 2017

\begin{abstract}
ABSTRAK
Ikan kakap merah (L. gibbus) adalah jenis ikan demersal dari famili Lutjanidae yang bernilai ekonomis penting dan banyak tertangkap di Indonesia. Informasi tentang kebiasaan makan dan aspek reproduksi ikan kakap merah di Indonesia masih relatif sedikit. Selain itu, telah terjadi penurunan stok ikan kakap merah di Selatan Banten selama 6 tahun terakhir (2008-2013). Penelitian ini bertujuan untuk mengkaji hubungan panjangberat, kebiasaan makan dan reproduksi ikan kakap merah.. Penelitian dilakukan selama 3 tahun $(2013,2015$ dan 2016). Ikan contoh diambil dari hasil penangkapan ikan oleh para nelayan dengan alat tangkap pancing rawai dasar dan pancing ulur dengan mata pancing no 7-10 yang didaratkan di Binuangeun-Banten. Analisis fekunditas dilakukan di Laboratorium dengan metode gravimetrik. Hasil penelitian menunjukkan bahwa ikan kakap merah jantan memiliki ukuran lebih panjang dibandingkan ikan betina, pola pertumbuhannya bersifat isometrik. Kebiasaan makan ikan kakap merah tergolong ikan karnivora dimana makanan utamanya adalah ikan dan kepiting (Portunidae). Nisbah kelamin jantan dan betina tidak seimbang yaitu 1: 1.53. Fekunditas berkisar 14.050596.243 butir dengan rata-rata 170869 butir, diameter telur berkisar 0,03-1,02 mm dan pola pemijahannya bersifat salin sebagian (partial spawner).
\end{abstract}

Kata Kunci: Pertumbuhan; kebiasaan makan; reproduksi; kakap merah; Banten

\section{ABSTRACT}

The humpback red snapper (Lutjanus gibbus) is the family of lutjanidae which has important economic value in Indonesian capture fisheries. In addition, there has been a sharp decline on the population of humpback red snapper in the Southern part of Banten during the last 6 years (2008-2013). This study aims to examine the growth function, food habits and reproductive biology of L. gibbus in the Southern part of Banten Waters. Fish samples were collected for 3 years (2013, 2015 and 2016) both from fishing ground and landing places in Binuangeun-Banten, caught by handline and bottom longline. The fecundity analysis was performed in Laboratory by gravimetric method. The results showed that the average size of males of humpback red snapper was longer than females with the growth pattern was isometric. The food habits of humpback red snapper was classified as carnivorous fish in which the main food item consist of fish and crab (Portunidae). Sex ratio of males and females were unbalance by 1: 1.53. The fecundity ranges from 14.050-596.243 eggs with an average of 170.869 eggs. The humpback red snapper found as partial spawner which eggs diameter ranged from 0,03 to 1,02 $\mathrm{mm}$.

Keywords: Growth; food habits; reproduction; Lutjanus gibbus; Banten 


\section{PENDAHULUAN}

Ikan kakap merah (Lutjanus spp.) adalah nama lokal untuk beberapa spesies anggota Famili Lutjanidae. Beberapa jenis anggota famili ini merupakan ikan demersal yang mendiami perairan tropis dan sub-tropis, bernilai ekonomis penting, dan banyak tertangkap di perairan Indonesia (Badrudin et al., 2008), yang diusahakan baik oleh nelayan lokal, komersil maupun rekreasi (Kamakuru \& Mgaya, 2004; Grandcourt et al., 2006: Heupel et al., 2010 dan Holloway et al., 2015). Kegiatan perikanan kakap merah di Banten tergolong perikanan skala kecil. Kegiatan perikanan kakap merah di Indonesia tergolong perikanan skala kecil dan industri. Perikanan skala kecil menggunakan alat tangkap pancing ulur (handline) dan jaring insang (giilnet) yang dioperasikan pada kapal berukuran < 5 GT (nelayan lokal dan komersil) dan 6-10 GT (rekreasi), kedalaman 30-150 meter, dengan jarak 12 mil dari garis pantai. Perikanan skala industri, menggunakan alat tangkap pancing ulur (handline) dan pancing rawai dasar (bottom longline) yang dioperasikan menggunakan kapal sekitar 90-100 GT dengan 3000-4000 mata pancing pada kedalaman 100-200 meter (ACIAR, 2003; Anggraeni, 2012).

Berdasarkan spesies, ikan kakap merah (L. gibbus) yang memiliki nama umum humpback red snapper dan nama lokal di Banten disebut sebagai ikan kikil. Panjang maksimum mencapai $500 \mathrm{~mm}$, umumnya $350 \mathrm{~mm}$ (Allen, 1985; Filotova 1980 dalam Karyaningsih et al., 1993; Anand \& Pillai, 2002; Martinez-Andrade, 2003). Spesies ini dapat dibedakan dari genus Lutjanus lainnya dengan ciri khusus yaitu badan berwarna merah menyala atau merah kecoklatan, gigi vomer membentuk huruf V terbalik, sirip ekor melebar dan membentuk cagak yang dalam (deeply forked), lempengan sirip ekor bagian atas membulat dan lebih besar daripada bagian bawahnya. Ikan L. gibbus biasa menghuni perairan berbatu, berkarang dan sedikit berlumpur (Badrudin et al., 2008; Allen, 1985). Penyebaran spesies kakap merah ini meliputi perairan IndoPasifik dari Kepulauan Line and Society sampai Afrika Timur, Australia sampai Selatan Jepang (White et al., 2013; Allen, 1985). Penyebaran di wilayah perairan Indonesia meliputi Laut Jawa, Kepulauan Karimunjawa, Selat Sunda, Selatan Jawa, Selatan/Barat Kalimantan, Timur Kalimantan, Perairan Sulawesi, Kepulauan Natuna, Kepulauan Lingga dan Kepulauan Riau lainnya pada kedalaman 30-100 meter (Allen, 1985; Marzuki \& Djamal, 1992).

Berbagai informasi biologis ikan L. gibbus telah dilaporkan oleh beberapa peneliti sebelumnya meliputi hubungan panjang-berat, nisbah kelamin dan fekunditas (Anand \& Pillai 2002; Heupel et al., 2010) dan kebiasaan makan (Martinez-Andrade, 2003; Nanami \& Shimose, 2013), informasi tentang aspek tersebut di Indonesia masih relatif sedikit (Imbalan, 2013; Holloway et al., 2015). Beberapa di antaranya adalah yang dilakukan di perairan Labuan, Banten yakni hubungan panjang-berat yang menunjukkan pola pertumbuhan allometrik negatif (Imbalan, 2013) dan makanan utama ikan ini adalah kepiting dan udang (Nanami \& Shimose, 2013).

Berdasarkan produksi tangkapan, telah terjadi penurunan stok ikan kakap merah di perairan Selatan Banten selama 6 tahun terakhir (2008-2013). Pada tahun 2008, produksi tercatat $34962 \mathrm{~kg} /$ tahun menurun menjadi $18433 \mathrm{~kg} /$ tahun pada 2013. Upaya penangkapan menurun dari 333 trip/tahun menjadi 304 trip/tahun dalam kurun waktu yang sama. Indeks kelimpahan stok (CPUE, catch per unit effort) juga mengalami penurunan dari $105 \mathrm{~kg} /$ trip/tahun menjadi $61 \mathrm{~kg} /$ trip/tahun (DKP, 2013). Kondisi ini menunjukkan perlunya pengelolaan yang lebih baik. Penelitian ikan kakap merah yang dilakukan di perairan Banten ini bertujuan untuk mengkaji pola pertumbuhan berdasarkan hubungan panjang-berat, kebiasaan makanan, dan beberapa aspek reproduksinya di perairan Selatan Banten. Diharapkan hasil penelitian dapat menjadi salah satu rujukan dalam praktek pemanfaatan dan pengelolaannya yang berkelanjutan.

\section{BAHANDANMETODE Waktu dan Lokasi Penelitian}

Penelitian berlangsung dalam periode waktu 2013, 2015 dan 2016 yang merupakan kegiatan riset BPPL (Balai Penelitian Perikanan Laut) di Pantai Selatan Banten, dengan pengambilan sampel dilakukan di TPI BinuangeunLebak, Banten. Tahun 2014 tidak dilakukan penelitian karena lokasi penelitian dialihkan ke tempat lain. Sampel ikan kakap merah yang digunakan berasal dari hasil tangkapan di beberapa daerah penangkapan (fishing ground) di kawasan tersebut (Gambar 1). 


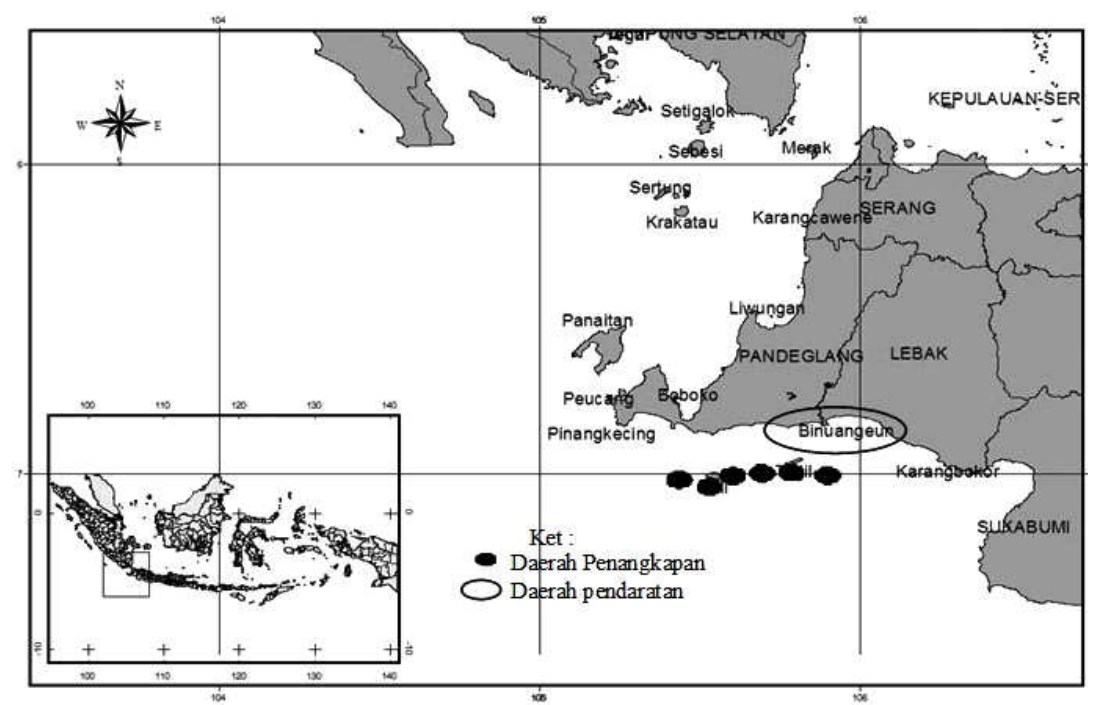

Gambar 1. Peta daerah penangkapan ikan kakap merah dan pendaratan ikan di Binuangeun, Banten.

Figure 1. Map of fishing ground of humpback red snapper and fish landing in Binuangeun, Banten.

\section{Pengumpulan Data}

Ikan kakap merah dipisahkan dari jenis ikan lainnya yang merupakan hasil tangkapan pancing rawai dasar dan pancing ulur dengan bermata pancing nomor 7-10. Sampel ikan terpilih diukur panjang cagak (Fork length, $F L$ ) dan panjang total (total length, TL) dengan menggunakan papan ukur berketelitian $1 \mathrm{~mm}$, dan ditimbang beratnya dengan timbangan digital berketelitian $1.0 \mathrm{~g}$. Pengukuran panjang dan berat ikan dilakukan oleh penulis, teknisi dan enumerator selama 20 hari setiap bulannya. Jumlah sampel ikan yang diukur sebanyak $10 \%$ per kapal dari total hasil tangkapan pancing rawai dasar dan pancing ulur dengan kedalaman sekitar 30 - 60 meter.

Sampel ikan yang akan dibedah dipisahkan, dimasukkan ke ice box dan diawetkan dengan es batu untuk pengamatan dan pengukuran gonad dan isi lambung. Pengamatan dan pengukuran isi lambung dilakukan di lapangan dengan bantuan kaca pembesar (loop) dan di Laboratorium menggunakan mikroskop binokuler dengan pembesaran 10x, kemudian diidentifikasi dan ditimbang beratnya menggunakan timbangan digital berketelitian $0.01 \mathrm{~g}$. Penentuan jenis kelamin (sex ratio) ditentukan dengan membedah ikan contoh menggunakan alat bedah kemudian diamati jenis kelaminnya.

Sampel gonad yang terkumpul diawetkan dengan larutan gilson untuk analisa fekunditas dan diameter telur dan larutan formalin $10 \%$ untuk analisa histologi gonad ikan. Analisis fekunditas dilakukan di Laboratorium dengan metode gravimetrik. Telur yang dianalisa adalah telur dari ikan matang gonad (TKG III-IV). Telur ditimbang sebanyak 0.1 g kemudian diencerkan menggunakan aquades kedalam cawan petri dan sedgewick rafter untuk memisahkan butiran telur. Telur dihitung jumlahnya dibawah mikroskop menggunakan bantuan counter. Pengukuran diameter telur dilakukan dengan mengambil gonad ikan betina dari TKG I-IV. Dari tiga bagian yaitu anterior, median dan posterior secara langsung terhadap butiran telur dan hasil preparasi histologi gonad. Pengukuran diameter telur menggunakan mikroskop binokuler dan mikroskop stereo discovery 8 dengan pantulan cahaya (perbesaran10x) yang dilengkapi dengan micrometer okuler secara acak minimal 100 butir telur per sampel.

\section{Analisis Data}

Analisis hubungan panjang-berat ikan bertujuan untuk mengetahui pola pertumbuhan ikan di alam, mengacu pada Effendie (1979) dengan rumus:

$\mathrm{W}=\mathrm{aL}^{\mathrm{b}}$ 1)

Keterangan :

$\mathrm{W}=$ berat ikan (gr); $\mathrm{L}=$ panjang ikan (cm); a dan $\mathrm{b}=$ konstanta.

Untuk menguji nilai $\beta=3$ atau $\beta \neq 3$ dilakukan uji $-\mathrm{t}$ (uji parsial), dengan hipotesis:

$\mathrm{H}_{0}: \beta=3$, hubungan panjang dan berat adalah isometrik

$\mathrm{H}_{1}: \beta \neq 3$, hubungan panjang dan berat adalah allometrik yaitu pola hubungan panjang-berat bersifat allometrik positif, bila $\mathrm{b}>3$ (pertambahan berat lebih cepat daripada pertambahan panjang), dan allometrik negatif, bila $\mathrm{b}<3$ (pertambahan panjang lebih cepat daripada pertambahan berat) (Effendie, 1979).

Berdasarkan pola pertumbuhan di atas, nilai faktor kondisi (k) dianalisis sebagai: 


$$
k=\frac{W}{a L^{b}} \text { atau } k=\frac{10^{5} W}{L^{3}} \text { bilamana allometrik }(\mathrm{b} \neq 3)
$$

atau isometrik $(b=3)$.

\section{Keterangan:}

$\mathrm{a}, \mathrm{b}=$ konstanta; $10^{5}=$ nilai yang diambil agar nilai $\mathrm{k}$ berkisar diantara 1 .

Evaluasi jenis makanan dengan menggunakan indek bagian terbesar (index of preponderance) merupakan gabungan dari dua metode, yaitu metode frekuensi kejadian dan volumetrik. Metode ini dikembangkan oleh Natarajan \& Jhingran (1961) dalam Effendie (1979) dengan rumus:

$I P_{i}(\%)=\frac{V_{i} x O_{i}}{\sum\left(V_{i} x O_{i}\right)} x 100 \%$

Keterangan:

$\mathrm{IP}_{\mathrm{i}}=$ indek bagian terbesar (index of preponderance); $\mathrm{V}_{\mathrm{i}}=$ persentase volume satu macam makanan; $\mathrm{O}_{\mathrm{i}}=$ persentase frekuensi kejadian satu mæcam makanan; $\mathrm{V}_{\mathrm{i}} * \mathrm{O}_{\mathrm{i}}=$ jumlah $\mathrm{V}_{\mathrm{i}} \times \mathrm{O}_{\mathrm{i}}$ dari semua macam makanan.

Berdasarkan nilai indek bagian terbesar (IBT), Nikolsky (1963) membedakan makanan ikan ada tiga golongan, yaitu: makanan utama jika nilai IBT $>40 \%$; makanan pelengkap jika nilai IBT $4-40 \%$ dan makanan tambahan, jika nilai IBT $<4 \%$.

Perbandingan jantan dan betina merujuk kepada Effendie (1979):

$\mathrm{X}=\mathrm{J}: \mathrm{B}$

Keterangan :

$\mathrm{X}=$ nisbah kelamin; $\mathrm{B}=$ jumlah ikan betina; $\mathrm{J}=$ jumlah ikan jantan.

Untuk menguji proporsi antara jumlah ikan jantan dan betina seimbang atau tidak dilakukan uji chi-square $\left(\chi^{2}\right)$ (Steel \& Torrie, 1993).

Penghitungan fekunditas dilakukan dengan mengambil gonad ikan yang sudah mencapai TKG III dan IV. Dalam penelitian ini contoh telur seberat $0.1 \mathrm{~g}$, kemudian diteliti sebaran ukuran telur dan jumlah telurnya. Fekunditas dihitung secara gravimetri dengan rumus Holden \& Raitt (1974):

$$
F=\frac{n x G}{g}
$$

Keterangan:

$\mathrm{F}=$ fekunditas; $\mathrm{n}=$ jumlah telur dalam sub sampel; $\mathrm{G}=$ berat gonad $(\mathrm{gr}) ; \mathrm{g}=$ berat gonad sub sample $(0.1 \mathrm{~g})$.

Hubungan antara fekunditas dengan panjang ikan dianalisis menggunakan rumus Bagenal (1978):

$\mathrm{F}=\mathrm{aL}^{\mathrm{b}}$

Keterangan:

$\mathrm{F}=$ fekunditas; $\mathrm{L}=$ panjang ikan; $\mathrm{a}$ dan $\mathrm{b}=$ konstanta yang didapat dari data.

Tipe pemijahan akan diduga berdasarkan jumlah modus yang akan diperoleh pada distribusi sebaran diameter telur yang dilihat di mikroskop.

\section{HASIL DAN BAHASAN Hasil}

\section{Struktur Ukuran Panjang}

Sebaran ukuran panjang ikan kakap merah jantan dengan jumlah sampel 240 ekor berkisar 103 - 360 mm FL dengan rata-rata $236.05 \mathrm{~mm}$ FL dan modus $229 \mathrm{~mm}$ FL $(32.50 \%)$. Sebaran ukuran panjang ikan kakap merah betina dengan jumlah sampel 337 ekor berkisar 147 - 324 mm FL dengan rata-rata $214.8 \mathrm{~mm}$ FL dan modus $229 \mathrm{~mm}$ FL $(42.14 \%)$ (Gambar 2).

\section{Hubungan Panjang dan Faktor Kondisi}

Berdasarkan jenis kelamin, persamaan hubungan panjang-berat ikan jantan adalah $\mathrm{W}=0.00002 \mathrm{~L}^{3.030}$ dan ikan betina adalah $\mathrm{W}=0.019 \mathrm{~L}^{3.033}$, dengan nilai koefesien determinasi $\left(\mathrm{R}^{2}\right)$ masing-masing 0.986 dan 0.973 (Gambar 3). Nilai tersebut menggambarkan bahwa $97 \%$ variasi berat dapat menjelaskan panjang ikan. Pola pertumbuhan ikan kakap merah jantan dan betina adalah isometrik yakni laju pertumbuhan panjang seimbang dengan laju pertumbuhan berat $(\mathrm{Ujit}, \mathrm{p}=0.05)$. 


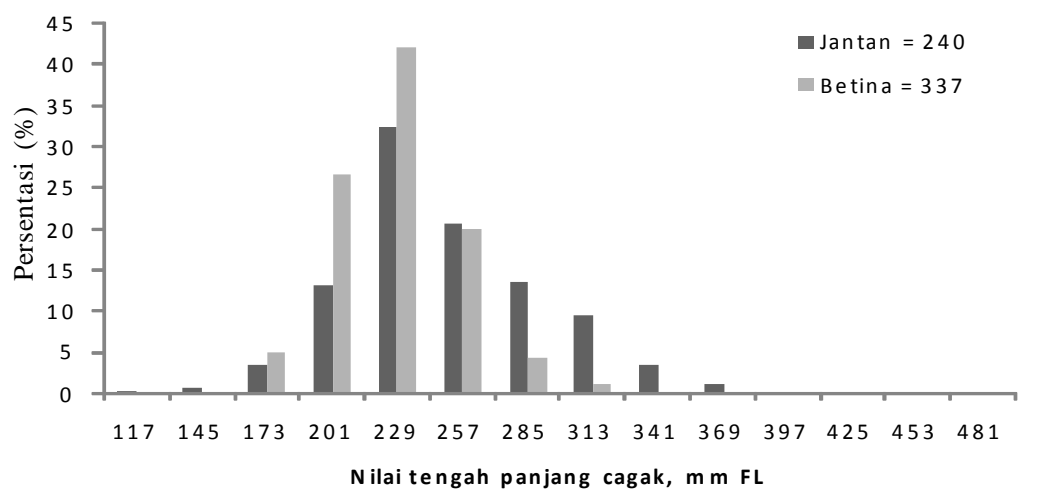

Gambar 2. Distribusi frekuensi panjang ikan kakap merah jantan dan betina di perairan Selatan Banten.

Figure 2. Length frequency distribution of humpback red snapper male and female in Southern Banten waters.
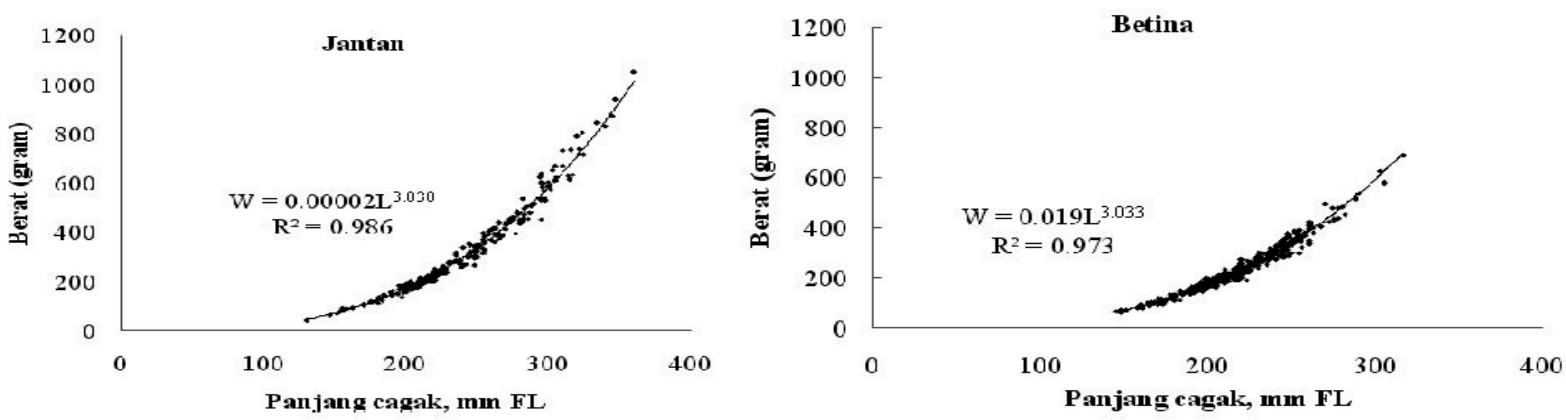

Gambar 3. Hubungan panjang - berat ikan kakap merah jantan dan betina di perairan Selatan Banten.

Figure 3. Length - weight relationship of humpback red snapper male and female in Southern Banten waters.

Faktor kondisi ikan kakap merah jantan berkisar 1.742.48 dengan rata-rata 2.16 dan betina berkisar 1.73-2.56 dengan rata-rata 2.15 . Nilai rata-rata faktor kondisi ikan jantan terendah pada bulan Desember 2016 (1.98 \pm 0.08$)$ dan tertinggi pada bulan Juli $2013(2.29 \pm 0.06)$ dan nilai rata-rata faktor kondisi ikan betina terendah pada bulan Desember $2016(1.97 \pm 0.10)$ dan tertinggi pada bulan Mei 2016 (2.27 \pm 0.10$)$ (Gambar 4).
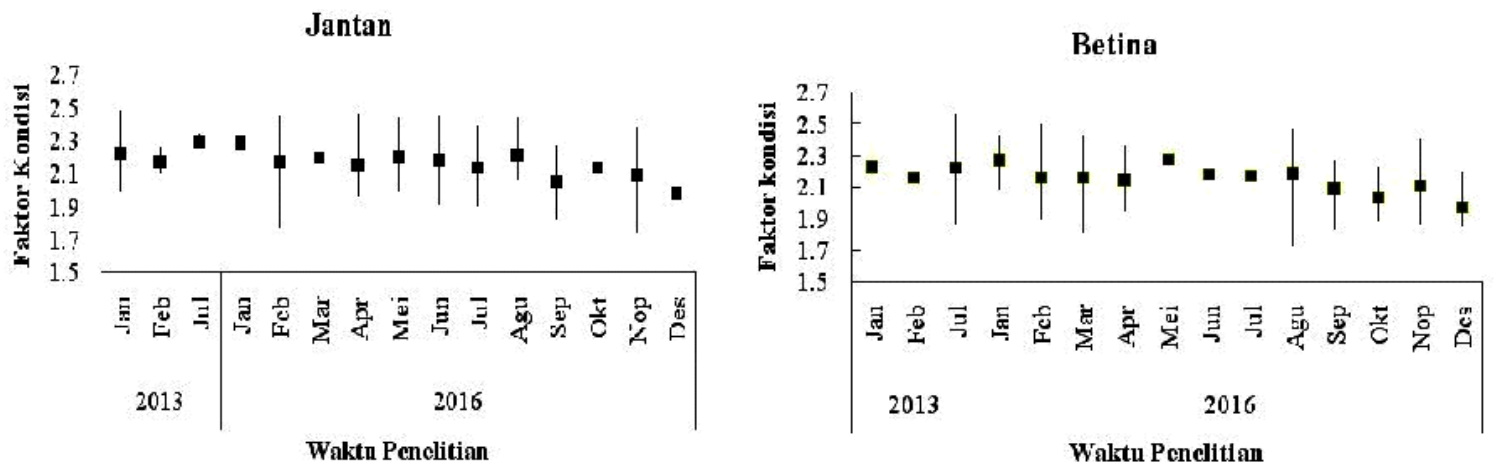

Gambar 4. Faktor kondisi ikan kakap merah jantan dan betina di perairan Selatan Banten berdasarkan waktu penelitian. Figure 4. Condition factor of humpback red snapper male and female in Southern Banten waters based on the time of the study.

\section{Kebiasaan Makanan}

Ikan kakap merah yang dianalisis kebiasaan makanannya berjumlah 505 ekor, dengan lambung dalam keadaan kosong sebesar 54.06\%. Jika mengacu kepada pendapat Nikolsky (1963) maka dapat dikatakan bahwa secara keseluruhan makanan utama ikan kakap merah adalah ikan (Fishes) dan kepiting (Portunidae) masing masing sebesar $49.17 \%$ dan $45.01 \%$. Makanan tambahannya adalah udang putih (Penaeidae) sebesar $3.70 \%$; rajungan (Portunidae) $1.41 \%$; sotong (Cephalopoda) $0.21 \%$; cacing (Polychaeta) $0.11 \%$; cumicumi (Loliginidae) $0.05 \%$; bintang laut (Ophiuroidea) $0.10 \%$; keong (Gastropoda) $0.02 \%$ dan udang mantis (Squillidae) 0.24\% (Gambar 5). 


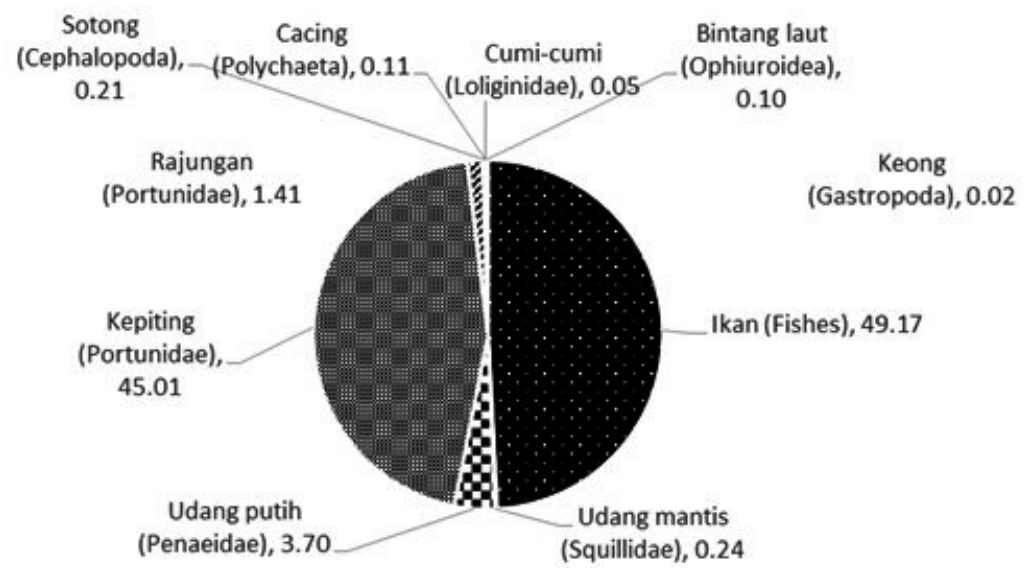

Gambar 5. Diagram indeks bagian terbesar ikan kakap merah di perairan Selatan Banten.

Figure 5. Diagram index of preponderance of humpback red snapper in Southern Banten waters.

Kebiasaan makanan ikan kakap merah setiap bulan disajikan pada Gambar 6. Bulan Januari dan Februari 2013, kebiasaan makan ikan kakap merah didominasi kepiting (Portunidae) sebesar 60.25\% dan 54.24\%. Pada Juli 2013, didominasi ikan (Fishes) dan kepiting (Portunidae) masingmasing sebesar $46.95 \%$ dan $44.33 \%$. Bulan Februari 2016 didominasi udang putih (Penaeidae) sebesar $43.47 \%$ dan bulan Maret, April - Juli 2016 didominasi kepiting (Portunidae) masing-masing sebesar 54.02\%; 59.52\%; 74.94\%; 61.16\% dan 61.85\%. Bulan Agustus, Oktober, Nopember dan Desember didominasi ikan (Fishes) masingmasing sebesar $77.63 \% ; 52.76 \% ; 70.64 \%$ dan $91.27 \%$.

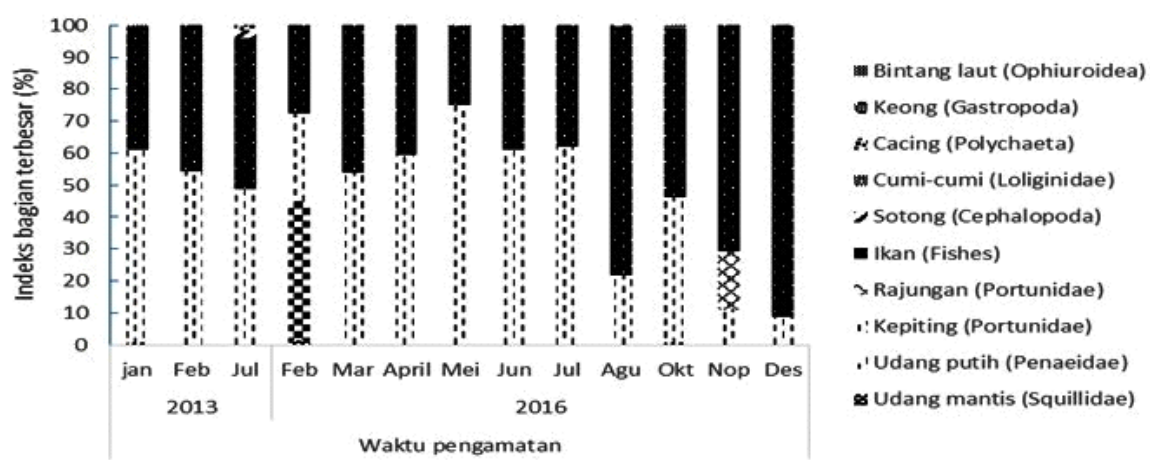

Gambar 6. Diagram indeks bagian terbesar ikan kakap merah di perairan Selatan Banten berdasarkan waktu pengamatan. Figure 6. Diagram index of preponderance of humpback red snapper in Southern Banten waters based on the time of the study.

Kebiasaan makanan ikan kakap merah berdasarkan selang kelas panjang adalah pada kelas ukuran panjang $105 \mathrm{~mm}$ (ikan muda) didominasi oleh ikan (Fishes), kemudian panjang 115 - $145 \mathrm{~mm}$, isi lambung dalam keadaan kosong. Ukuran panjang 155-305 mm (ikan dewasa) didominasi kepiting dan ikan (Fishes). Panjang $315 \mathrm{~mm}$, isi lambung dalam keadaan kosong, panjang 325 $-345 \mathrm{~mm}$ didominasi kepiting (Gambar 7).

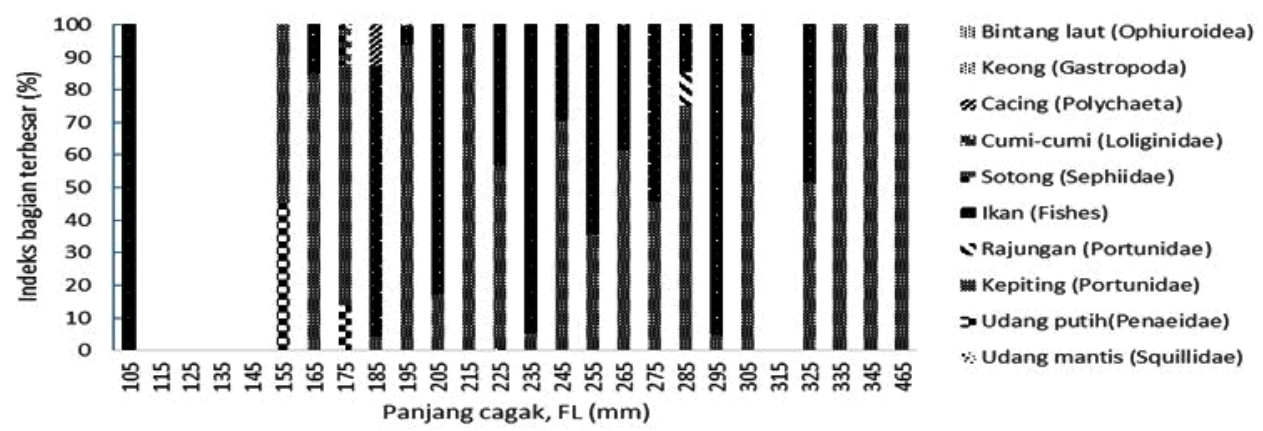

Gambar 7. Diagram indeks bagian terbesar ikan kakap merah di perairan Selatan Banten berdasarkan kelas panjang.

Figure 7. Diagram index of preponderance of humpback red snapper in Southern Banten waters based on fork length. 


\section{Nisbah Kelamin}

Proporsi jumlah ikan kakap merah jantan terhadap betina selama periode waktu penelitian adalah 256 jantan berbanding 392 betina. Dengan demikian nisbah kelamin ikan kakap merah di perairan Selatan Banten adalah 1:1.53. Nisbah kelamin ikan kakap merah secara keseluruhan tidak mengikuti pola $1: 1$ (Chi square, $\mathrm{p}=0.05$ ). Nisbah kelamin menurut waktu pengamatan selama 15 bulan (Januari, Februari, Juli 2013 dan Januari - Desember 2016), diperoleh nilai $\chi^{2}{ }_{\text {hitung }}$ sebesar 58.93 dan $\chi_{\text {tabel }}^{2}$ sebesar 23.685 (Tabel 1). Hal ini menunjukkan bahwa nisbah kelamin jantan dan betina berbeda nyata pada taraf kepercayaan $95 \%\left(\chi_{\text {hitung }}^{2}>\chi^{2}\right.$ tabel $)$ yang berarti bahwa nisbah kelamin ikan kakap merah jantan dan betina adalah tidak seimbang $(1 \neq 1)$.

Tabel 1. Nisbah kelamin ikan kakap merah di Selatan Banten berdasarkan waktu pengamatan Table 1. Sex ratio of humpback red snapper in Southern Banten based on the time of the study

\begin{tabular}{|c|c|c|c|c|c|}
\hline \multirow{2}{*}{ Bulan/Month } & \multirow{2}{*}{ Jantan/Male } & \multirow{2}{*}{ Betina/Female } & \multirow{2}{*}{ Total } & \multirow{2}{*}{$\begin{array}{c}\text { Nisbah kelamin } \\
(\mathbf{J}: \mathbf{B}) \\
\end{array}$} & \multirow[b]{2}{*}{$\chi 2$ hitung } \\
\hline & & & & & \\
\hline \multicolumn{6}{|l|}{2013} \\
\hline Januari & 16 & 20 & 36 & $1: 1.25$ & 0.44 \\
\hline Februari & 4 & 10 & 14 & $1: 2.50$ & 2.57 \\
\hline Juli & 2 & 22 & 24 & $1: 11.0$ & 16.67 \\
\hline \multicolumn{6}{|l|}{2016} \\
\hline Januari & 5 & 17 & 22 & $1: 3.40$ & 6.55 \\
\hline Februari & 18 & 42 & 60 & $1: 2.33$ & 9.60 \\
\hline Maret & 6 & 12 & 18 & $1: 2.00$ & 2.00 \\
\hline April & 15 & 26 & 41 & $1: 1.73$ & 2.95 \\
\hline Mei & 26 & 27 & 53 & $1: 1.04$ & 0.02 \\
\hline Juni & 40 & 65 & 105 & $1: 1.62$ & 5.95 \\
\hline Juli & 25 & 37 & 62 & $1: 1.48$ & 2.32 \\
\hline Agustus & 26 & 34 & 60 & $1: 1.30$ & 1.07 \\
\hline September & 16 & 22 & 38 & $1: 1.37$ & 0.95 \\
\hline Oktober & 16 & 6 & 22 & $1: 0.37$ & 4.55 \\
\hline Nopember & 26 & 40 & 66 & $1: 1.54$ & 2.97 \\
\hline \multirow[t]{2}{*}{ Desember } & 15 & 12 & 27 & $1: 0.80$ & 0.33 \\
\hline & & & & & 58.93 \\
\hline Total & 256 & 392 & 648 & $1: 1.53$ & 28.54 \\
\hline
\end{tabular}

\section{Fekunditas dan Diameter Telur}

Fekunditas ikan kakap merah yang diamati sebanyak 54 ekor ikan pada TKG III dan IV berkisar 14 050-596 243 butir rata-rata 170869 butir dengan kisaran bobot tubuh antara 123 - 465 gr dan kisaran berat gonad antara $1.58-$ 12.30 gr. Dalam penelitian ini fekunditas dihubungkan dengan panjang cagak dan berat tubuh ikan (Gambar 8). Hubungan antara fekunditas dengan panjang cagak ikan kakap merah di perairan Selatan Banten menghasilkan koefesien determinasi $\left(\mathrm{R}^{2}\right)$ sebesar 0.141. Hal ini menunjukkan bahwa $14 \%$ dari keragaman nilai fekunditas ikan kakap merah yang dapat dijelaskan oleh panjang cagak. Koefesien korelasi (r) sebesar 0.375 yang berarti hubungan panjang cagak dan fekunditas ikan kakap merah adalah kurang erat. Hubungan antara fekunditas dengan berat tubuh ikan kakap merah menghasilkan koefesien determinasi $\left(\mathrm{R}^{2}\right)$ sebesar 0.111 dan koefesien korelasi (r) sebesar 0.333 .

Berdasarkan pengukuran diameter telur secara langsung dan hasil preparasi histologi, maka diameter telur ikan kakap merah berkisar $0.03-1.02 \mathrm{~mm}$. TKG I terdapat 1 modus yaitu pada diameter telur $0.1 \mathrm{~mm}$ dengan persentasi kehadiran $73.46 \%$. TKG II terdapat 2 modus yaitu pada diameter telur $0.15 \mathrm{~mm}$ dan $0.25 \mathrm{~mm}$ dengan persentasi $26.0 \%$ dan $18.0 \%$. TKG III terdapat 4 modus yaitu pada diameter telur $0.10 \mathrm{~mm}, 0.40 \mathrm{~mm}, 0.55 \mathrm{~mm}$ dan 0.75 mm dengan persentasi $99.01 \%, 18.03 \%, 3.27 \%$ dan $0.82 \%$. TKG IV terdapat 5 modus yaitu pada diameter telur $0.10 \mathrm{~mm}, 0.30 \mathrm{~mm}, 0.65 \mathrm{~mm}, 0.90 \mathrm{~mm}$ dan $1.2 \mathrm{~mm}$ dengan persentasi $14.0 \%, 6.0 \%, 8.0 \%, 10.0 \%$ dan 2.0\% (Gambar 9). 

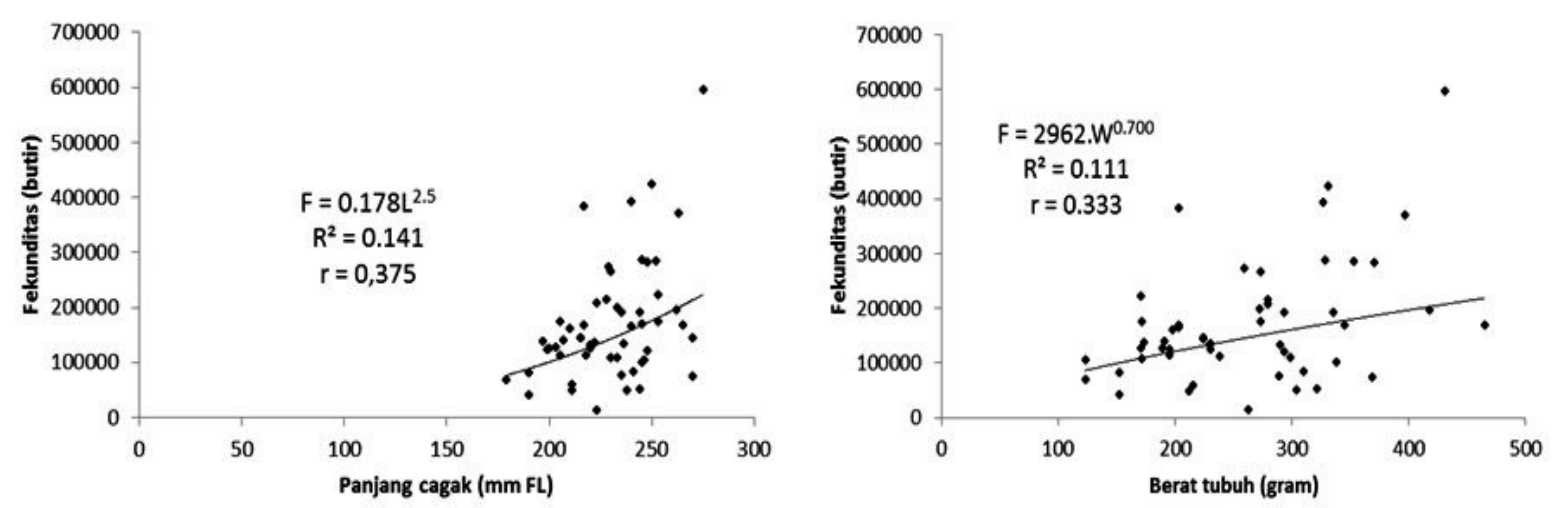

Gambar 8. Hubungan panjang - fekunditas dan berat tubuh - fekunditas kakap merah di Selatan Banten.

Figure 8. Length-fecundity and wieght-fecundity relationship of humpback red snapper in Southern Banten.

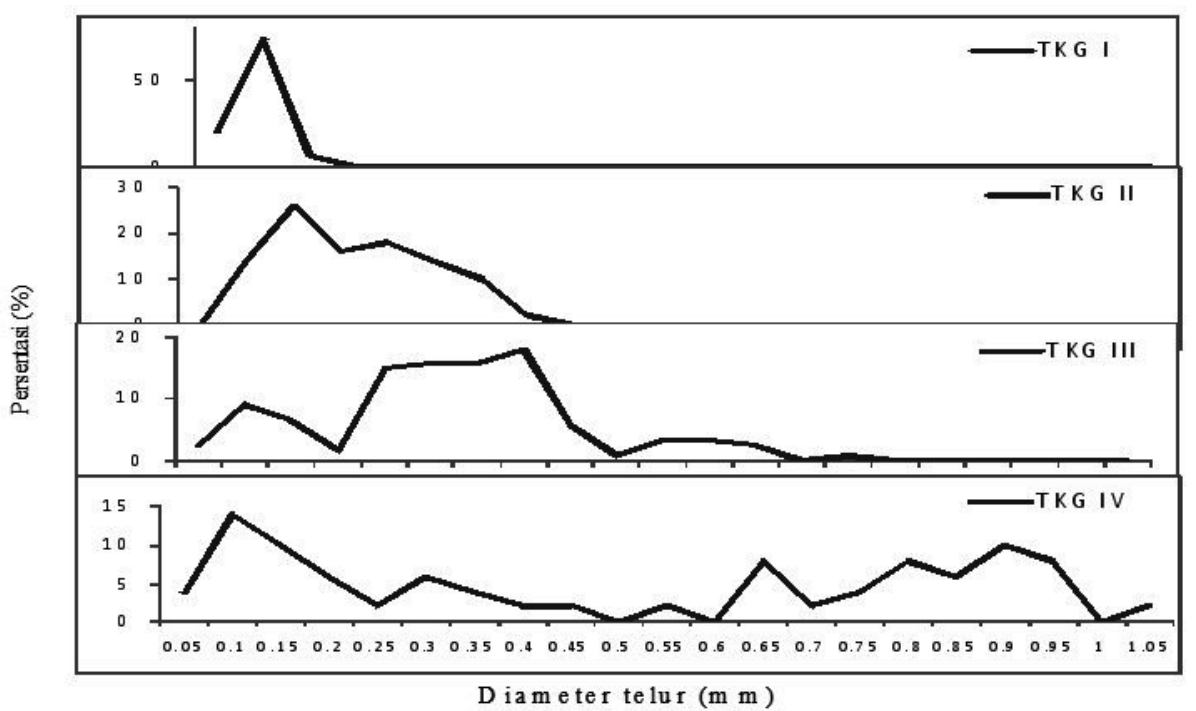

Gambar 9. Sebaran diameter telur ikan kakap merah di perairan Selatan Banten.

Figure 9. Distribution of egg diameters of humpback red snapper in Southern Banten waters.

\section{Bahasan}

\section{Struktur Ukuran Panjang}

Sebaran ukuran panjang ikan kakap merah hasil tangkapan pancing ulur dan pancing rawai dasar secara keseluruhan berkisar 103-415 mm FL dengan rata-rata 222 mm FL, berkisar 103-360 mm FL untuk jantan dan berkisar 147-324 mm FL untuk betina. Ikan jantan memiliki ukuran yang lebih panjang dibandingkan ikan betina. Hasil penelitian ini sama dengan hasil penelitian Nanami et al., (2010) yang menemukan ikan jantan sedikit lebih besar dari ikan betina. Apabila dianalisa dengan bentuk grafik sebaran ukuran panjang terlihat lebih menjulur ke kiri yang berarti ikan-ikan muda dan dewasa yang banyak tertangkap dibandingkan ikan tua. Hal ini berkaitan dengan penggunaan mata pancing no 7-10 sehingga ikan yang tertangkap didominasi oleh ikan berukuran kecil sehingga ke depan perlu adanya pengaturan ukuran mata pancing $>$ No. 10 agar ikan yang tertangkap lebih selektif. Selain itu daerah tangkapan pancing rawai dasar dan pancing ulur di sekitar perairan Binuangeun tidak terlalu jauh dengan jarak 5-50 mil dari garis pantai sehingga ikan kakap merah yang tertangkap umumnya berukuran kecil. Badrudin et al., (2008) dan Allen (1985) mengatakan habitat ikan kakap merah dewasa menghuni perairan berbatu dan terumbu karang sampai kedalaman $60 \mathrm{~m}$, sedangkan ikan muda lebih menyukai daerah pantai yang mempunyai kawasan mangrove.

Hasil penelitian ini memperoleh struktur ukuran yang lebih besar dibandingkan dengan hasil penelitian Imbalan (2013) di Pandeglang-Banten (Indonesia) berkisar 225387 mm dengan rata-rata 299.58 mm TL; Patty (2005) di Perancis, berkisar 150-240 mm; Holloway et al., (2015) di perairan Bunaken, Sulawesi Utara (Indonesia) berkisar 151312 mm FL; Nanami et al., (2010) di Jepang berkisar 179391 mm FL (jantan) dan 177-324 mm FL (betina); Heupel et al., (2010) di perairan Australia berkisar 262-418 mm FL (jantan) dan 227-356 mm FL (betina) lebih kecil dari hasil penelitian Druzhimin \& Filotova (1980) dalam Karyaningsih et al., (1993) di Gulf of Aden berkisar 265475 mm. Allen (1999) menyatakan panjang ikan kakap merah 
di perairan Australia, Great Barrier Reef, Asia dan Indo Pasifik mencapai $500 \mathrm{~mm}$. Badrudin et al., (2008) dan White et al., (2013) menambahkan ikan kakap merah dapat mencapai panjang $500 \mathrm{~mm}$, umumnya $400 \mathrm{~mm}$. Perbedaan ukuran panjang ikan kakap merah diduga berkaitan dengan perbedaan alat tangkap yang digunakan dan perbedaan daerah tangkapan. Nikolsky (1963) menyatakan bahwa perbedaan ukuran ikan juga dipengaruhi oleh kondisi lingkungan, kelimpahan dan ketersediaan makanan, suhu dan cahaya pada tiap perairan yang berbeda.

\section{Hubungan Panjang Berat dan Faktor Kondisi}

Pertumbuhan ikan kakap merah jantan dan betina di perairan Selatan Banten adalah isometrik, artinya pertumbuhan panjang seimbang dengan pertumbuhan beratnya (ikan tumbuh ideal, tidak gemuk dan tidak kurus). Hal ini berbeda dengan hasil penelitian Imbalan (2013) yang menemukan pertumbuhan ikan kakap merah di perairan Labuan, Pandeglang Banten adalah allometrik negarif dan hasil penelitian Holloway et al., (2015) di perairan Bunaken, Sulawesi Utara adalah allometrik positif. Menurut Bagenal (1978), faktor-faktor yang menyebabkan perbedaan nilai b selain perbedaan spesies adalah perbedaan jumlah dan variasi ukuran ikan yang diamati, tahap perkembangan ikan, jenis kelamin dan faktor lingkungan. Apabila dikaitkan dengan ketersediaan makanan, maka pertumbuhan ikan kakap merah bersifat issometrik diduga makanan ikan kakap merah di Selatan Banten berlimpah. Effendie (2002) menyatakan bahwa makanan yang diambil akan mempengaruhi pertumbuhan, kematangan tiap individu dan keberhasilan hidupnya.

Nilai faktor kondisi yang diperoleh selama penelitian berkisar 0.73-2.56 yang menunjukkan bahwa kondisi ikan baik. Mengacu pada Effendie (1979) hasil ini menandakan ikan kakap merah masih berada pada batas ambang kondisi yang baik dengan kisaran nilai faktor kondisi antara 1-3. Nilai faktor kondisi ikan kakap merah setiap bulannya mengalami perubahan. Baik jantan dan betina, nilai faktor kondisi terendah terjadi pada bulan Desember dan tertinggi pada bulan Mei dan Juli. Rendahnya nilai faktor kondisi pada Desember diduga adanya pengaruh pola musim yang terjadi di perairan Selatan Banten. Bulan Desember merupakan musim barat (musim hujan) dimana kecepatan arus dan angin tinggi sehingga ikan harus beradaptasi terhadap perubahan kondisi perairan yang berpengaruh pada ketersediaan makanan. Tingginya nilai faktor kondisi pada bulan Mei dan Juli merupakan musim timur dimana kondisi perairan cukup baik.

\section{Kebiasaan Makanan}

Jika mengacu kepada struktur anatomi ikan, maka ikan kakap merah tergolong karnivora. Hal ini dicirikan dengan tapis insang sedikit, pendek, kaku dan jarang; rongga mulut bergigi kuat dan tajam; lambung berbentuk tabung; dan ususnya pendek (Affandi et al., 2009). Berdasarkan hasil penelitian, makanan utama ikan kakap merah adalah ikan (Fishes) dan kepiting (Portunidae) masing masing sebesar $49.17 \%$ dan $45.01 \%$. Makanan tambahannya adalah udang putih (Penaeidae) sebesar $3.70 \%$; rajungan (Portunidae) $1.41 \%$; sotong (Cephalopoda) $0.21 \%$; cacing (Polychaeta) $0.11 \%$; cumi-cumi (Loliginidae) $0.05 \%$; bintang laut (Ophiuroidea) $0.10 \%$; keong (Gastropoda) $0.02 \%$ dan udang mantis (Squillidae) $0.24 \%$. Selain ikan, kepiting di perairan Selatan Banten keberadaannya juga melimpah sehingga perairan Selatan Banten merupakan habitat tumbuh dan berkembang yang baik bagi ikan kakap merah. Isi lambung ikan kakap merah yang diteliti dalam keadaan kosong sebesar $54.06 \%$. Hal ini diduga berkaitan dengan variasi waktu menangkap ikan dengan waktu ikan kakap merah makan. Metode penangkapan ikan kakap merah dilakukan pada saat ikan mencari makan, artinya saat itu kondisi perut ikan dalam keadaan kosong. Hasil penelitian ini tidak jauh berbeda dengan hasil penelitian Nanami \& Shimose (2013), makanan utama ikan kakap merah adalah kepiting kemudian diikuti oleh udang. Allen (1985) dalam Martinez-Andrade (2003) menyatakan hasil penelitian terhadap kebiasaan makan ikan kakap merah di perairan Tahiti terdiri dari ikan (30\%), Decapoda (30\%), bentik invertebrata lainnya (10\%), Cephalopoda (10\%) dan lainnya (20\%).

Kebiasaan makanan ikan kakap merah setiap bulannya menunjukkan persentasi yang tidak terlalu berbeda yaitu didominasi oleh ikan dan kepiting. Hal ini diduga berkaitan dengan morfologi ikan dimana ikan kakap merah hidup di dasar perairan yang dicirikan dengan mata, bukaan mulut, bentuk gigi, bentuk lambung, lemak dalam perut (Nanami \& Shimose 2013) dan otolith ikan yang berukuran besar untuk dapat beradaptasi hidup dan mencari makan di dasar perairan sehingga makanannya adalah ikan - ikan demersal dan krustasea.

Kebiasaan makanan ikan kakap merah berdasarkan selang kelas panjang menunjukkan ikan kakap merah yang berukuran kecil didominasi oleh ikan kecil (Fishes) dan ikan berukuran besar diominasi oleh kepiting (Portunidae). Hal ini diduga berkaitan dengan ketersediaan makanan di Selatan Banten cukup melimpah. Hal ini sesuai dengan pernyataan Effendie (2002) bahwa faktor - faktor yang menentukan suatu jenis ikan akan memakan suatu jenis organisme adalah ukuran makanan, ketersediaan makanan, warna, rasa, tekstur makanan dan selera ikan terhadap makanan sehingga dapat dikatakan bahwa ukuran ikan tidak terlalu berpengaruh terhadap jenis makanan yang dimanfaatkan. Jika mengacu kepada Moyle \& Chech (1988), berdasarkan jumlah dan variasi makanannya maka ikan kakap merah termasuk kelompok stenophagus yaitu ikan yang memakan makanan yang sedikit jenisnya.

\section{Nisbah Kelamin}


Pada penelitian ini, secara keseluruhan ikan kakap betina di perairan Selatan Banten lebih melimpah dibandingkan jantan dengan nisbah kelamin jantan dan betina adalah 1:1.53. Hal ini menjelaskan bahwa nisbah kelamin ikan kakap merah jantan dan betina tidak seimbang. Hasil penelitian ini sama dengan penelitian Anand \& Pillai (2002) di India bahwa nisbah kelamin ikan kakap merah tidak seimbang dengan perbandingan jantan dan betina adalah 1:0.67 dan hasil penelitian Heupal et al., (2010) di pantai timur Australia dengan perbandingan jantan dan betina adalah 1:0.17.

Jika melihat hasil uji chi square, nisbah kelamin jantan dan betina berdasarkan waktu penelitian berbeda nyata pada taraf kepercayaan $95 \%\left(\chi_{\text {hitung }}^{2}>\chi_{\text {tabee }}^{2}\right)$ yang berarti bahwa nisbah kelamin ikan kakap merah jantan dan betina tidak seimbang $(1 \neq 1)$. Hal ini diduga bahwa ikan kakap merah di perairan Selatan Banten tidak berada dalam satu area pemijahan, sehingga peluang tertangkapnya berbedabeda. Pada Januari-Maret 2016, nilai nisbah kelamin ikan di perairan didominasi ikan betina (diduga terjadi proses pemijahan) dan bulan Mei 2016 hampir mendekati seimbang (diduga menjelang proses pemijahan). Bulan Juni-September 2016 juga didominasi oleh betina (diduga terjadi proses pemijahan), sedangkan bulan Oktober dan Desember 2016 didominasi oleh jantan (diduga melakukan ruaya pemijahan). Menurut Nikolsky (1963), perbandingan jenis kelamin jantan dan betina dapat berubah menjelang dan selama musim pemijahan.

\section{Fekunditas dan Diameter Telur}

Fekunditas ikan kakap merah di perairan Selatan Banten pada TKG III dan IV berkisar 14 050-59 6243 butir dengan rata-rata 170869 butir. Hasil penelitian ini lebih besar dari hasil penelitian Anand \& Pillai (2002), fekunditas ikan kakap jenis L. gibbus berkisar 46 774-130 698. Nilai fekunditas yang tinggi ini berarti ikan kakap merah memiliki potensi reproduksi yang tinggi pula, sehingga berpengaruh pula pada tingginya kesedian stok dan rekruitmen ikan kakap merah. Hal ini juga berkaitan dengan ketersediaan makanan ikan kakap merah di Selatan Banten melimpah sehingga fekunditasnya lebih besar. Effendie (2002) menyatakan ikan-ikan yang hidup di perairan yang kurang subur maka produksi telurnya rendah.

Hal ini sesuai dengan Grimes (1987), yang menyatakan ikan kekakapan umumnya memiliki fekunditas yang tinggi dan pendugaan fekunditas untuk spesies yang sama juga bervariasi pada lokasi yang berbeda. Anand \& Pillai (2002) menyatakan bahwa variasi fekunditas disebabkan karena perbedaan ukuran gonad, pemilihan ikan yang matang gonad dan jenis ikan (spesies). Baxter (1963) dalam Holden \& Raitt (1974) menyatakan pendugaan fekunditas tergantung pada beberapa faktor antara lain jumlah absolut telur yang diproduksi oleh jenis ikan yang mengalami salin total (total spawner) dan salin sebagian (partial spawner), serta tingkat perbedaan ukuran telur yang dipijahkan pada suatu musim dengan telur yang masih dibawa untuk pemijahan musim berikutnya. Effendie (2002) menambahkan variasi fekunditas berhubungan dengan komposisi umur, faktor lingkungan seperti persediaan makanan, kepadatan populasi dan suhu perairan.

Kedua persamaan antara panjang cagak ikanfekunditas dan berat tubuh-fekunditas menunjukkan bahwa fekunditas ikan kakap merah semakin bertambah dengan bertambahnya panjang cagak dan berat tubuh, namun hubungannya kurang erat dengan korelasi yang kecil ( $r=0.375$ dan $r=0.333$ ). Hal ini mengindikasikan bahwa ikan yang berukuran besar tidak selalu mempunyai fekunditas yang lebih tinggi. Hal ini sesuai dengan pernyataan Effendie (2002), fekunditas relatif maksimum terjadi pada golongan ikan muda dan pada ikan-ikan yang tua dan besar ukurannya mempunyai fekunditas relatif lebih kecil.

Diameter telur ikan kakap merah L. gibbus berkisar 0.03-1.02 mm. Diameter telur ikan kakap hasil penelitian ini lebih besar dibandingkan dengan diameter telur ikan kakap jenis L. sanguieneus yaitu 0.03-0.69 mm (Karyaningsih et al., 1992) dan jenis L. kasmira di Lakshadweep yaitu $0.80 \mathrm{~mm}$ (Anand \& Pillai, 2002). Pada TKG IV, diameter telur berkisar 0.06-1.02 $\mathrm{mm}$ yang menunjukkan bahwa telur dalam keadaan matang. Hal ini sesuai dengan pernyataan Basyarie at al., (1991) dalam Karyaningsih et al., (1992) bahwa telur pada tahap berkembang bila diameternya mencapai $<0.35 \mathrm{~mm}$ dan tahap matang bila diameternya antara $0.35-0.60 \mathrm{~mm}$.

Dengan melihat perkembangan diameter telur, TKG II terdapat 2 modus, TKG III terdapat 4 modus dan TKG IV terdapat 5 modus. Hal ini menunjukkan bahwa pola pemijahan ikan kakap merah bersifat salin sebagian (partial spawner) yaitu ikan yang memijahkan telurnya tidak sekaligus dalam satu musim pemijahan. Telur yang sudah matang dan siap untuk dipijahkan pada waktu dan tempat yang sesuai maka akan dikeluarkan lebih dulu, kemudian kelompok diameter yang belum matang akan terus berkembang sampai matang dan akan dikeluarkan pada waktu dan tempat yang berbeda. Effendie (2002) menyatakan bahwa persentasi distribusi diameter telur terhadap komposisi tingkat kematangan gonad digunakan untuk menduga terjadinya musim pemijahan. Pada setiap kali mendekati musim pemijahan, ikan yang mempunyai satu musim pemijahan yang pendek atau panjang dalam satu tahun, akan ditandai dengan peningkatan persentasi TKG yang tinggi, sedangkan ikan yang mempunyai musim pemijahan sepanjang tahun, didapatkan komposisi TKG terhadap berbagai stadium dengan persentase yang tidak sama. Dapat dikatakan bahwa berdasarkan distribusi 
diameter telur, maka ikan kakap melangsungkan pemijahannya terus menerus pada kisaran waktu yang lama.

\section{KESIMPULAN}

Hubungan panjang berat ikan kakap merah bersifat isometrik. Kebiasaan makan ikan kakap merah tergolong ikan karnivora dimana makanan utamanya adalah ikan dan kepiting (Portunidae) dan makanan tambahannya adalah udang putih (Penaeidae), rajungan (Portunidae), sotong (Cephalopoda), cacing (Polychaeta), cumi-cumi (Loliginidae), bintang laut (Ophiuroidea), keong (Gastropoda) dan udang mantis (Squillidae). Nisbah kelamin ikan kakap merah jantan dan betina tidak seimbang yaitu 1:1.53. Fekunditas berkisar 14 050-596 243 butir dengan rata-rata 170869 butir, diameter telur berkisar 0.03$1.02 \mathrm{~mm}$ dan pola pemijahannya bersifat salin sebagian (partial spawner).

\section{PERSANTUNAN}

Tulisan ini merupakan hasil dari kegiatan riset penelitian karakteristik biologi perikanan, habitat sumberdaya dan potensi produksi sumberdaya ikan di WPP 573 (Samudera Hindia Selatan Jawa dan Nusa Tenggara) di Balai Penelitian Perikanan Laut Tahun 2013, 2015 dan 2016.

\section{DAFTAR PUSTAKA}

ACIAR. (2003). Report of the Final 4th Stock Assessment Workshop. Bogor, 18-20 Maret 2003.

Affandi, R., Sjafei, D.S., Rahardjo, M.F., \& Sulistiono. (2009). Fisiologi Ikan. Pencernaan dan Penyerapan Makanan (p. 240). Bogor. IPB Press.

Allen, G. (1985). FAO Species Catalogue. Volume 6/ : Snappers of The World. An annotated and illustrated catalogue of lutjanid species known to date. Rome: FAO.

Allen, G. (1999). A Field Guide for Anglers and Divers/: Marine Fishes of South-East Asia. Singapore: Periplus Editions.

Anand, P. V., \& Pillai, N. (2002). Reproductive biology of some common coral reef fishes of the Indian EEZ. Jurnal Marine Biological Association of India. 44 (1\&2), 122-135.

Anggraeni, D. (2012). Supporting Sustainability of Snapper Fisheries in Arafura and Timor Sea Through Supply Chain. Laporan Arafura and Timor Sea Ecosystem Action (ATSEA). Sustainable Fisheries Partnership.
DKP (Dinas Kelautan dan Perikanan). (2013). Buku Tahunan Statistik Perikanan Tangkap Kabupaten Lebak 2013. Dinas Kelautan dan Perikanan Kabupaten Lebak.

Badrudin, Sumiono, B., \& Rahmat, E. (2008). Kakap Merah. (p. 40). Jakarta: Penebar Swadaya.

Bagenal, T. B. (1978). Ecology of freshwater fish production (pp. 75-101). Oxford: Balckwell Scientific Publications.

Effendie, M. I. (1979). Metoda Biologi Perikanan (p. 112). Bogor: Yayasan Dewi Sri.

Effendie, M. I. (2002). Biologi Perikanan (Revisi) (p. 163). Bogor: Yayasan Pustaka Nusatama.

Grandcourt, E. M., Abdessalaam, T. Z. Al, \& Francis, F. (2006). Age, growth, mortality and reproduction of the blackspot snapper, Lutjanus fulviflamma (Forsskal, 1775), in the southern Arabian Gulf. Fisheries Research. 78(2-3), 203-210.

Grimes, C. B. (1987). Reproductive biology of the Lutjanidae/ : a review. J.J. Polovina \& S. Ralston (Eds.) Tropical Snappers and Groupers/ : Biology and Fisheries Management. 239-294.

Heupel, M. R., Williams, A. J., Welch, D. J., Davies, C. R., Penny, A., Kritzer, J. P., Mapstone, B. (2010). Demographic characteristics of exploited tropical lutjanids/: a comparative analysis. Fish. Bull. 108, 420432.

Holden, M. J., \& Raitt. D. (1974). Manual of Fisheries Sciences. Part 2. Methods of Resource Investigation and Their Application. FAO Fish.

Holloway, C. J., Bucher, D. J., \& Kearney, L. (2015). A Preliminary Study of the Age and Growth of Paddletail Snapper Lutjanus gibbus (Forsskål 1775 ) in Bunaken Marine Park, North Sulawesi, Indonesia. Asian Fisheries Science. 28, 186-197.

Imbalan, A. (2013). Telaah Aspek Biologi dan Aspek Perikanan Ikan Kakap Merah (Lutjanus Gibbus Forsskal, 1775 dan Lutjanus erythropterus Bloch, 1790) yang Didaratkan di Pelabuhan Perikanan Pantai (PPP) Labuan Pandeglang, Banten. Tesis. Universitas Indonesia.

Kamakuru, A. T., \& Mgaya, Y. D. (2004). The food and feeding habits of blackspot snapper, Lutjanus fulviflamma ( Pisces/ : Lutjanidae ) in shallow waters 
of Mafia Island , Tanzania. African Journal of Ecology, $42,49-58$.

Karyaningsih, S., Djamal, R., \& Junus, S. (1992). Pengamatan Fekunditas dan Diameter Telur Ikan Kakap Merah (Lutjanus sanguineus). Jurnal Penelitian Perikanan Laut. (68), 67-82.

Karyaningsih, S., Marzuki, S., \& Djamal, R. (1993). Beberapa Aspek Biologi Jenis Kekakapan Laut Dalam (Pristipomoides typus) di Perairan Timor Timur dan Sekitarnya. Jurnal Penelitian Perikanan Laut. (78), 92-99.

Martinez-Andrade, F. (2003). A comparison oflife histories and ecological aspects among snappers (Pisces: Lutjanidae). PhD Thesis. Louisiana State University.

Marzuki, S., \& Djamal, R. (1992). Perkiraan Parameter Pertumbuhan dan Laju Kematian Kakap Merah (Lutjanus sanguineus) di Perairan Laut Jawa. Jurnal Penelitian Perikanan Laut. (65), 31-39.

Moyle, P. B. \& J.J. Cech. 1988. Fishes. An Introduction to Ichthyology. Second Edition. Prentice Hall. New Jersey.

Nanami, A., Kurihara, T., Kurita, Y., Aonuma, Y., Suzuki, N., \& Yamada, H. (2010). Age, growth and reproduction of the humpback red snapper Lutjanus gibbus off Ishigaki Island, Okinawa. Ichthyological Research. 57(3), 240-244.

Nanami, A., \& Shimose, T. (2013). Interspecific differences in prey items in relation to morphological characteristics among four lutjanid species (Lutjanus decussatus, L. fulviflamma, L. fulvus and L. gibbus). Environmental Biology of Fishes. 96(5), 591-602.

Nikolsky, G. V. (1963). The Ecology of Fishies (p. 352). London: Academic Press.

Patty, W. (2005). Penentuan Pertumbuhan Ikan Tropis dari Analisa Frekwensi Ukuran Panjang Ikan. Ilmu Kelautan, UNDIP. 10(4), 191-198.

Steel, R., \& Torrie, H. (1993). Prinsip dan Prosedur statistika Suatu Pendekatan Biometrik. Jakarta.: PT. Gramedia Pustaka Utama.

White, W.T., Last, P.R., Dharmadi, Faizah, R., Chodrijah, U., Prisantoso, B.I., Pogonoski, J.J., Puckridge, M., Blader, S.J.M. (2013). Market fishes of Indonesia (Jenis jenis ikan di Indonesia). Canberra. ACIAR Monograph N0. 155. 